\title{
Brown midrib corn shredlage in diets for high-producing dairy cows
}

\author{
L. M. Vanderwerff, L. F. Ferraretto, and R. D. Shaver ${ }^{1}$ \\ Department of Dairy Science, University of Wisconsin, Madison 53706
}

\section{ABSTRACT}

A novel method of harvesting whole-plant corn silage, shredlage, may increase kernel processing and physically effective fiber. Improved fiber effectiveness may be especially advantageous when feeding brown midrib (BMR) corn hybrids, which have reduced lignin content. The objective of this study was to determine the effect of feeding TMR containing BMR corn shredlage (SHRD) compared with BMR conventionally processed corn silage (KP) or KP plus chopped alfalfa hay $(\mathrm{KPH})$ on intake, lactation performance, and total-tract nutrient digestibility in dairy cows. The KP was harvested using conventional rolls (2-mm gap) and the self-propelled forage harvester set at $19 \mathrm{~mm}$ of theoretical length of cut, whereas SHRD was harvested using novel crossgrooved rolls (2-mm gap) and the self-propelled forage harvester set at $26 \mathrm{~mm}$ of theoretical length of cut. Holstein cows ( $\mathrm{n}=120 ; 81 \pm 8 \mathrm{~d}$ in milk at trial initiation), stratified by parity, days in milk, and milk yield, were randomly assigned to 15 pens of 8 cows each. Pens were randomly assigned to 1 of 3 treatment diets, SHRD, $\mathrm{KP}$, or $\mathrm{KPH}$, in a completely randomized design using a 2-wk covariate period with cows fed a common diet followed by a 14-wk treatment period with cows fed their assigned treatment diet. The TMR contained (dry matter basis) KP or SHRD forages (45\%), alfalfa silage $(10 \%)$, and a concentrate mixture (45\%). Hay replaced $10 \%$ of KP silage in the KPH treatment TMR (dry matter basis). Milk, protein, and lactose yields were $3.4,0.08$, and $0.16 \mathrm{~kg} / \mathrm{d}$ greater, respectively, for cows fed KP and SHRD than KPH. A week by treatment interaction was detected for milk yield, such that cows fed SHRD produced or tended to produce $1.5 \mathrm{~kg} / \mathrm{d}$ per cow more milk, on average, than cows fed KP during 6 of the 14 treatment weeks. Component-corrected milk yields were similar among treatments. Cows fed $\mathrm{KPH}$ had greater milk fat concentration than cows fed KP and SHRD (3.67 vs. $3.30 \%$ on average). Consumption of dry matter, rumination activity, and sorting behavior were similar among treatments. Ruminal in situ starch digestibility was greater for SHRD than KP forages,

Received March 6, 2015.

Accepted April 12, 2015.

${ }^{1}$ Corresponding author: rdshaver@wisc.edu and total-tract dietary starch digestibility was greater for SHRD than KP. Milk yield and starch digestibility were greater for SHRD than KP. Lack of improvement in milk fat content and rumination activity for SHRD compared with KP and reduced milk fat content for SHRD compared with KPH, however, suggest no improvement in physically effective fiber from the longer theoretical length of cut used with SHRD in a BMR hybrid.

Key words: corn shredlage, physically effective neutral detergent fiber, digestibility, dairy cow

\section{INTRODUCTION}

In recent years, harvesting whole-plant corn silage (WPCS) as shredlage (SHRD; Shredlage LLC, Tea, SD) has gained widespread interest among dairy producers and nutritionists. Shredlage is harvested with a commercially available self-propelled forage harvester (SPFH) fitted with after-market cross-grooved cropprocessing rolls, and the $\mathrm{SPFH}$ set for a longer theoretical length of cut (TLOC) than commonly used.

Physically effective neutral detergent fiber (peNDF) can be increased in the diet by increasing the TLOC of forages (Mertens, 1997). Benefits of increased peNDF include increased rumination activity, salivary buffering, and rumen mat formation (Mertens, 1997; Zebeli et al., 2012). Milk fat yield is also related to dietary peNDF content (Mertens, 1997). Yang et al. (2001) reported that milk yield was maximized when a greater forage-to-concentrate ratio and longer forage particle size were used together. There may, however, be a limit to increasing the TLOC in forages; increasing length increases rumen bulk. Dado and Allen (1995) reported that an increase in rumen bulk has a depressing effect on the percentage of large meals consumed by dairy cattle. However, Yang and Beauchemin (2007) reported that, provided the overall dietary NDF was kept low, DMI was not affected by increased TLOC of the forage. Feed bunk sorting is another concern with increased TLOC of forages. Leonardi et al. (2005) suggested that when increasing the mean particle length of forages with greater TLOC it is important to minimize the proportion of particles retained on the coarsest sieves to prevent sorting. 
Hybrid type may also influence the physical effectiveness of WPCS. Brown-midrib (BMR) WPCS generally has greater in vitro NDF digestibility (ivNDFD) than conventional hybrids (Ferraretto and Shaver, 2015). Therefore, BMR WPCS may not elicit the same chewing activity as conventional WPCS and, thus, is less effective as a source of peNDF (Zebeli et al., 2012). Evidence for this, however, is equivocal. Oba and Allen (2000) reported that despite increased NDF digestibility, the physical effectiveness of BMR WPCS was not compromised. In contrast, Taylor and Allen (2005) found that feeding BMR WPCS decreased rumination activity and, thus, physical effectiveness.

Potential improvements in starch digestibility appears to be an important benefit of the cross-grooved processing rolls used in the harvest of SHRD. A previous trial completed by Ferraretto and Shaver (2012) reported greater kernel-processing score for SHRD compared with conventionally processed WPCS (KP). An increase in total-tract dietary starch digestibility (ttSTD) was reported which appeared to be related to increased ruminal starch digestibility for the SHRD. Ferraretto and Shaver (2012) also reported that cows fed SHRD produced more FCM and ECM than cows fed KP WPCS, with the increase thought to be related primarily to greater kernel processing and starch digestibility (Bal et al., 2000).

The primary objective of our study was to determine the effect of feeding BMR SHRD compared BMR KP on lactation performance and starch digestibility in dairy cattle fed TMR. A secondary objective was to determine the effect of feeding BMR SHRD compared with BMR KP with added chopped alfalfa hay (KPH) in TMR to evaluate SHRD as a source of peNDF.

\section{MATERIALS AND METHODS}

Nineteen hectares of a BMR silage corn hybrid (F2F627; Mycogen Seeds, Dow AgroSciences LLC, Indianapolis, IN) were planted on May 8, 2013, at a density of 75,000 seeds per hectare at University of Wisconsin-Madison Agricultural Research Station (Arlington, WI). The KP and SHRD were harvested at approximately one-half milk line stage of kernel maturity on September 18, 2013, with SHRD harvested in the morning and KP harvested in the afternoon. The field was harvested in alternating strips in an attempt to maintain similar nutrient composition for the SHRD and KP treatments. A Claas $940 \mathrm{SPFH}$ (Claas Jaguar, Claas of America Inc., Omaha, NE) equipped with SHRD processing rolls (Scherer Design Engineering Inc., Tea, SD) set for 26-mm TLOC, 2-mm roll gap, and $32 \%$ roll speed differential [(fast speed - slow speed)/fast speed] was used to harvest SHRD. The same SPFH equipped with a conventional Claas type 0130500.2 processor (Claas Jaguar, Claas of America Inc.) set for 19-mm TLOC, 2-mm roll gap, and $40 \%$ roll speed differential was used to harvest KP. Both SHRD and KP were inoculated with Lactobacillus buchneri 40788 and Pediococcus pentosaceus 12455 (Biotal Buchneri 500, Lallemand Animal Nutrition North America, Milwaukee, WI) at $5.0 \times 10^{5} \mathrm{cfu} / \mathrm{g}$ of forage. The silages were stored in side-by-side 3 -m diameter silo bags for approximately 4.5 mo before initiation of the feeding trial on January 30, 2014.

All experimental protocols were approved by the Animal Care and Use Committee of the College of Agriculture and Life Sciences at the University of Wisconsin-Madison. One hundred twenty Holstein cows averaging $81 \pm 8 \mathrm{DIM}$ and $717 \pm 9 \mathrm{~kg}$ of BW at trial initiation were stratified by parity (primi- and multiparous), DIM, and milk yield and randomly assigned to 15 pens of 8 cows each in a completely randomized design in the University of Wisconsin-Madison EmmonsBlaine freestall milking parlor dairy facility (Arlington, WI). Each balanced pen consisted of 2 primiparous and 6 multiparous cows. Pens were randomly assigned to a treatment TMR (Table 1) in a 16-wk continuouslactation experiment that included a 2 -wk covariate period in which all pens were fed a common diet (Table 1) containing the general herd nonexperimental conventional-hybrid SHRD in TMR followed by a 14 -wk treatment period where pens were fed their assigned treatment TMR containing BMR WPCS. The TMR treatments contained KP, KPH, or SHRD. Treatment TMR were formulated to be isonitrogenous and trace minerals and vitamins were supplemented to meet or exceed NRC (2001) guidelines. All cows received bST (Posilac, Elanco Animal Health, Greenfield, IN) every $14 \mathrm{~d}$ starting on $\mathrm{d} 1$ of the covariate period.

Experimental diets were mixed and fed once daily. The pens were supplied with TMR to allow for $5 \%$ refusals, with daily DMI determined on a pen basis throughout the study. Daily pen refusals were recorded each morning before new feed delivery using feeding management software (Feed Supervisor, Supervisor Systems, Dresser, WI). Daily pen DMI was measured as the difference between the as-fed feed offered and asis feed refusals (orts) multiplied by the DM content of the TMR. Body weight on a pen basis and BCS (1 to 5 in 0.25-unit increments; Wildman et al. 1982) on an individual cow basis were recorded every $14 \mathrm{~d}$ starting in the second covariate week and continuing throughout the trial. Measurements of BCS were averaged by pen before statistical analysis. Body weight change (BWC) was determined by regression of the treatment period BW measurements over time. 
Table 1. Ingredient and nutrient composition of the experimental diets ${ }^{1}$

\begin{tabular}{|c|c|c|c|c|}
\hline Ingredient, \% DM & $\mathrm{COV}^{2}$ & KP & $\mathrm{KPH}$ & SHRD \\
\hline \multicolumn{5}{|l|}{ Forage } \\
\hline Herd corn shredlage & 44.95 & - & - & - \\
\hline Brown midrib corn silage & - & 44.95 & 34.96 & - \\
\hline Brown midrib corn shredlage & - & - & - & 44.95 \\
\hline Alfalfa haylage & 9.99 & 9.99 & 9.99 & 9.99 \\
\hline Dry-chopped, alfalfa hay & - & - & 9.99 & - \\
\hline \multicolumn{5}{|l|}{ Concentrate $^{3}$} \\
\hline Dry-ground, shelled corn & 14.23 & 14.23 & 17.67 & 14.23 \\
\hline Soybean meal, expeller & 4.99 & 4.99 & 4.23 & 4.99 \\
\hline Soybean meal, solvent & 8.84 & 8.84 & 7.69 & 8.84 \\
\hline Corn gluten feed, dried & 11.14 & 11.14 & 9.61 & 11.14 \\
\hline Partially hydrogenated tallow ${ }^{4}$ & 1.92 & 1.92 & 1.92 & 1.92 \\
\hline Calcium carbonate & 1.38 & 1.38 & 1.38 & 1.38 \\
\hline Sodium bicarbonate & 0.77 & 0.77 & 0.77 & 0.77 \\
\hline Trace mineral salt ${ }^{5}$ & 0.38 & 0.38 & 0.38 & 0.38 \\
\hline Potassium carbonate $^{6}$ & 0.31 & 0.31 & 0.31 & 0.31 \\
\hline Urea & 0.28 & 0.28 & 0.28 & 0.28 \\
\hline Magnesium oxide & 0.27 & 0.27 & 0.27 & 0.27 \\
\hline Vitamin premix ${ }^{7}$ & 0.19 & 0.19 & 0.19 & 0.19 \\
\hline Magnesium-potassium-sulfur ${ }^{8}$ & 0.19 & 0.19 & 0.19 & 0.19 \\
\hline Rumensin premix ${ }^{9}$ & 0.13 & 0.13 & 0.13 & 0.13 \\
\hline Smartamine- $\mathrm{M}^{10}$ & 0.04 & 0.04 & 0.04 & 0.04 \\
\hline
\end{tabular}

${ }^{1}$ Treatments were the diet containing conventionally processed corn silage (KP), KP with added dry-chopped alfalfa hay $(\mathrm{KPH})$, or corn shredlage (SHRD; Shredlage LLC, Tea, SD).

${ }^{2} \mathrm{COV}=$ covariate period diet, formulated to provide $45 \%$ herd non-brown midrib corn shredlage.

${ }^{3}$ Concentrate for KP and SHRD diets contained $26.8 \% \mathrm{CP}, 5.5 \% \mathrm{ADF}, 14.0 \% \mathrm{NDF}$, and $26.0 \%$ starch (DM basis); KPH concentrate contained $24.7 \% \mathrm{CP}, 6.5 \% \mathrm{ADF}, 12.2 \% \mathrm{NDF}$, and $30.2 \%$ starch (DM basis).

${ }^{4}$ Energy Booster (Milk Specialties Global Animal Nutrition, Carpentersville, IL).

${ }^{5}$ Contained $88 \%$ sodium chloride, $0.002 \%$ cobalt, $0.2 \%$ copper, $0.012 \%$ iodine, $0.18 \%$ iron, $0.8 \%$ manganese, $0.006 \%$ selenium, and $1.4 \%$ zinc (Vita Plus, Madison, WI).

${ }^{6}$ DCAD Plus (minimum of $48.5 \%$ K; Church \& Dwight Co. Inc., Princeton, NJ).

${ }^{7}$ Vitamin A, 3,300,000 IU/kg; vitamin D, 1,100,000 IU/kg; vitamin E, 11,000 IU/kg (Country Mix Inc., Madison, WI).

${ }^{8}$ Dynamate (11\% magnesium, $18 \%$ potassium, $22 \%$ sulfur; The Mosaic Co., Plymouth, MN).

${ }^{9}$ Rumensin (Elanco Animal Health, Greenfield, IN).

${ }^{10}$ Smartamine-M (Adisseo, Alpharetta, GA).

Cows were milked 2 times daily in a double-16 parlor (Metatron P21; GEA Farm Technologies, Bakel, the Netherlands) and milk yield was recorded daily on individual cows throughout the trial (DairyComp 305; Valley Agricultural Software, Tulare, CA) and composited by pen by week before statistical analysis. Individual cow milk samples collected weekly from morning and evening milkings for 2 consecutive days were composited by pen by week before component analysis. Milk composites were analyzed for fat, true protein, lactose, and MUN concentrations by infrared analysis and SCC by flow cytometry (AgSource Milk Analysis Laboratory, Menominee, WI) using a CombiFoss $6600 \mathrm{FT}+/$ FC (Foss Electric, Hillerød, Denmark), with average daily yields of fat, protein, and lactose calculated from those data for each week. Yields of 3.5\% FCM, SCM, and ECM were calculated according to NRC (2001) equations. Actual milk, 3.5\% FCM, SCM, and ECM feed efficiencies were calculated by pen and week using average daily pen-based yield and DMI data. Estimated diet energy concentrations were calculated by summing the $\mathrm{NE}_{\mathrm{L}}$ (Mcal) from milk production [milk yield $\times$ $(0.0929 \times$ fat $\%+0.0563 \times$ protein $\%+0.0395 \times$ lactose \%)], required for maintenance (0.08 Mcal of $\mathrm{NE}_{\mathrm{L}} /$ $\mathrm{kg}$ of $\left.\mathrm{BW} \times \mathrm{BW}^{0.75}\right)$, and in $\mathrm{BWC}(\mathrm{BWC} \times 5.34 \mathrm{Mcal}$ of $\mathrm{NE}_{\mathrm{L}} / \mathrm{kg}$ of $\mathrm{BW}$ ) (NRC, 2001), and then dividing the sum by DMI.

All cows were fitted with a rumination-monitoring system (Heatime; SCR Engineers Ltd., Netanya, Israel) before trial initiation and daily rumination data of individual cows was collected. The system consisted of rumination loggers, stationary readers, and software for processing the electronic data (Data Flow 1 version 4.7, SCR Engineers Ltd.). A neck collar positioned the logger on the left side of the neck. Data were calculated and summarized in 2-h intervals and stored in the memory of the logger. Before each milking, data collected by the activity-monitoring system were read by a transceiver unit placed on an archway at the milking parlor entrance and recorded by the activity-monitoring system 
software installed on an on-farm computer. Data were averaged by pen by week before statistical analysis.

Weekly samples of TMR, corn silage and shredlage, alfalfa haylage and hay, and concentrates were collected throughout the trial. Samples were dried at $60^{\circ} \mathrm{C}$ for $48 \mathrm{~h}$ in a forced-air oven to determine DM content, ground to pass a 1-mm Wiley mill (Thomas Scientific, Swedesboro, NJ) screen, composited biweekly (alfalfa haylage and hay only), and subsampled before sending to Dairyland Laboratories Inc. (Arcadia, WI). Analyses included absolute DM, OM (method 942.05; AOAC International, 2012), CP (method 990.03; AOAC International, 2012), ether extract (method 2003.05; AOAC International, 2012), NDF using $\alpha$-amylase and sodium sulfite (Van Soest et al., 1991), and starch according to Bach Knudsen, (1997; YSI Biochemistry Analyzer; YSI Inc., Yellow Springs, OH). Particle size of TMR, SHRD, $\mathrm{KP}$, and alfalfa haylage and hay were determined on undried, unground samples using the Penn State Particle Separator (PSPS) as described by Kononoff et al. (2003) or the Wisconsin Oscillating Particle Separator (WPS; ANSI, 2001). Dried, unground concentrate and dry corn samples were particle sized by dry sieving using a Tyler Ro-Tap Shaker (model RX-29, Tyler, Mentor, $\mathrm{OH})$ containing sieves with 4,760-, 2,380-, 1,190-, 595-, 297-, 149-, and 63- $\mu \mathrm{m}$ apertures plus a bottom pan with mean particle size calculated using a log normal distribution (Baker and Herrman, 2002). Ruminal ivNDFD $(30 \mathrm{~h})$ on SHRD, KP and alfalfa haylage samples were determined at Dairyland Laboratories Inc. on dried 1-mm screen-ground samples using an Ankom Daisy Incubator (Ankom Technology Corporation, Fairport, NY), as described by Holden (1999). Using undried, unground samples of SHRD and KP, corn silage kernel processing score (CSPS; Ferreira and Mertens, 2005) and fermentation profile (Muck and Dickerson, 1988) were determined at Dairyland Laboratories Inc.

Feed sorting was evaluated for 3 consecutive days during the second covariate week and wk 7 and 13 of the treatment period. Individual daily pen samples (TMR and orts) were analyzed for particle size as described by Kononoff et al. (2003). Sorting was calculated as the actual DMI of each fraction expressed as a percentage of the predicted DMI, as described by Leonardi and Armentano (2003); values $<100 \%$ indicate selective refusals, those $>100 \%$ indicate preferential consumption, and those equal to $100 \%$ indicate no sorting.

Fecal samples were collected 6 times on 4 consecutive days to cover a 24 -h feeding cycle during the second covariate week and wk 7 and 13 of the treatment period. Samples were collected per rectum and composited by pen at each time point. Samples were frozen at $-20^{\circ} \mathrm{C}$, dried at $60^{\circ} \mathrm{C}$ for $72 \mathrm{~h}$ in a forced-air oven, ground to pass a 1-mm Wiley mill (Thomas Scientific, Swedes- boro, NJ) screen. Total-tract DM, OM, CP, NDF, and starch digestibilities were determined using lignin (method 973.18; AOAC International, 2012) as an internal marker. Ort samples were collected daily during the fecal sampling period. Treatment TMR, fecal, and ort samples were composited by week (TMR samples), pen within week (ort samples), or cow within pen within week (fecal samples); the composited samples were analyzed for DM, OM, CP, NDF, starch, and lignin, as previously described. Total-tract starch digestibility was also calculated from fecal starch concentration using the equation $[100 \times(0.9997-0.0125 \times$ fecal starch, \% DM)] (Fredin et al., 2014).

Two cows were removed from the study because of health issues. One was removed due to toxic mastitis and another was removed and later euthanized due to hemorrhagic bowel syndrome. Milk data were removed for 1 cow due to an injury for wk 8, 9, and 10 and for 2 other cows with left displaced abomasum during treatment wk 13 and 14. Rumination data were removed for 9 cows considered to be outliers. Outlier analysis was performed using the PROC UNIVARIATE procedure of SAS (SAS Institute, 2004) with outliers considered when outside of the $95 \%$ confidence interval of the data set.

Data were analyzed using PROC MIXED (SAS Institute, 2004) for a completely randomized design with a covariate adjustment. The fixed effects were covariate, treatment, week, and treatment $\times$ week; pen within treatment was considered to be a random effect. Week of treatment was the repeated measure using the firstorder autoregressive covariance structure, which provided best fit according to Sawa's Bayesian information criteria. Degrees of freedom were calculated using the Kenward-Roger option. Means were determined using the least squares means statement and treatment means were compared using the Bonferroni's $t$-test option after a significant overall treatment F-test. Bonferroni's $t$-test is a sequentially rejective test based on the Holm-Bonferroni method (Holm, 1979). Interaction effects were partitioned using the SLICE option (SAS Institute, 2004). Pen was the experimental unit. Statistical significance and trends were considered at $P$ $\leq 0.05$ and $P>0.05$ to $P \leq 0.10$, respectively. Body weight change and estimated diet $\mathrm{NE}_{\mathrm{L}}$ were analyzed using the same model but without including covariance or repeated measures.

A subsequent in situ trial was conducted in the University of Wisconsin tiestall barn (Dairy Cattle Center, Madison, WI) using 3 ruminally cannulated, mid-lactation, multiparous Holstein cows fed a TMR containing (DM basis) alfalfa haylage (44.5\%), corn silage (26.8\%), alfalfa hay $(10.7 \%)$, wheat straw $(6.5 \%)$, and concentrate mixture (11.5\%). Individual samples of SHRD 
and KP from 2 randomly selected weeks (wk 7 and 13) of the lactation trial were evaluated for starch $(12 \mathrm{~h})$ and NDF (24 h) ruminal in situ digestibilities. Dacron polyester cloth bags $(9 \times 18 \mathrm{~cm})$ containing 5 -g DM samples (approximately $15 \mathrm{~g}$, as fed) of the respective treatments were incubated in duplicate within each cow. Samples were not dried or ground before incubation to most accurately evaluate the effects of processing done during harvest (Johnson et al., 1999). The in situ bags for the respective treatments for each time point were placed in a nylon laundry bag $(30 \times 40 \mathrm{~cm})$ and then positioned in the ventral rumen. Bags were moistened in warm water before incubation. Each laundry bag contained a blank bag to allow correction for any infiltration of DM into sample bags. After removal, samples were soaked in cold water before washing twice in a commercial washing machine with cold water during 12-min cycles. Two bags for each treatment (0-h bags) were soaked for $30 \mathrm{~min}$ in tepid tap water and washed with the rest of the sample bags. The bags were dried in a forced-air oven at $60^{\circ} \mathrm{C}$ for $48 \mathrm{~h}$. Residues were ground through a 1-mm Udy mill screen (Udy Corp., Boulder, $\mathrm{CO})$ for nutrient analysis. Samples were sent to Dairyland Laboratories Inc. (Arcadia, WI) and analyzed for starch and NDF, as described previously. Data were analyzed using PROC MIXED (SAS Institute, 2004). The model included treatment, week, and treatment $\times$ week as fixed effects and cow as a random effect. Statistical significance and trends were declared at $P \leq$ 0.05 and $P>0.05$ to $P<0.10$, respectively.

\section{RESULTS AND DISCUSSION}

Chemical composition, fermentation profile, and physical form of KP and SHRD, as well as chemical composition and physical form of alfalfa haylage and hay are in Table 2. Both SHRD and KP were similar in nutrient composition and fermentation profile and were of good quality (Kung and Shaver, 2000; NRC, 2001). High ivNDFD for KP and SHRD reflected the use of a BMR hybrid (Oba and Allen, 2000) in our study. The alfalfa hay used in the KPH diet was of low quality based on high lignin and NDF contents and low ivNDFD, whereas the alfalfa haylage was of average quality based on moderate NDF content and low ivNDFD (NRC, 2001). Lower-quality hay was sourced for this experiment because of interest in the roughage value of the treatments.

Corn silage processing score (percent starch passing through a $4.75-\mathrm{mm}$ screen) was $72.4 \pm 3.6 \%$ for SHRD versus $67.6 \pm 6.5 \%$ for $\mathrm{KP}$, indicating that, on average, kernel breakage was greater for SHRD than KP. The coefficient of variation for CSPS, determined on samples obtained weekly during the feeding trial, was
$5.0 \%$ for SHRD and $9.6 \%$ for KP, indicating more consistent processing for SHRD. A frequency distribution of the CSPS data is in Figure 1; $57 \%$ of SHRD and $36 \%$ of KP samples were above a score of $70 \%$, which has been defined as excellent kernel processing (Ferreira and Mertens, 2005).

For WPCS samples, SHRD had a greater percentage of particles retained on the coarsest screens for both particle-sizing methods. The mean particle length determined by the WPS was greater for SHRD than KP (11.4 vs. $10.0 \mathrm{~mm}$ ). Percentage of particles retained on the coarsest screen of the PPS was similar for SHRD $(20.1 \%)$ and chopped alfalfa hay (18.3\%). The hay, however, had a shorter mean particle size than SHRD (4.0 vs. $11.4 \mathrm{~mm})$ due to a greater proportion of particles retained on the finest screen and bottom pan for the hay (25.0 and $31.0 \%$, respectively) compared with SHRD (12.5 and 4.6\%, respectively). Mean particle size was similar for alfalfa haylage $(11.7 \mathrm{~mm})$ and SHRD $(11.4 \mathrm{~mm})$. Percentage of particles retained on the coarsest screen of the PSPS, however, was greater for alfalfa haylage $(29.6 \%)$ than SHRD (18.3\%). As alfalfa haylage comprised the same percentage of DM in each treatment TMR, the haylage particle size had no effect on particle size differences among diets.

The TMR nutrient composition and physical form are in Table 3. Diet nutrient composition was similar for KP and SHRD, whereas slight differences were observed for $\mathrm{KPH}$ relative to those diets with greater DM, CP, NDF, and lignin contents and lesser ether extract, NFC, and starch contents. All treatment diets, however, met or exceeded NRC (2001) nutrient guidelines for high-producing dairy cows in mid-lactation. The percentage of TMR particles retained on the top, or coarsest, screen of the PSPS was greater for SHRD than $\mathrm{KP}$ or $\mathrm{KPH}$, whereas the percentage retained on the top 2 screens was similar for SHRD and KP (46.0 vs. $45.2 \%$ ). Mean particle size determined using the WPS was greatest for SHRD and lowest for KPH.

Sorting behavior against coarse particles was observed for all treatments (Table 4), as indicated by the percentage of predicted intake for the top screen of the PSPS being less than 100\%. Despite an increased proportion of particles on the top screen for the SHRD TMR (Table 3), increased sorting behavior was not observed for SHRD compared with KP or KPH $(P>$ $0.10)$. This is in agreement with previous observations for SHRD versus KP reported by Ferraretto and Shaver (2012). The lack of sorting does contrast with Leonardi et al. (2005), who suggested that particles above 26.9 $\mathrm{mm}$ should be minimized. The SHRD TMR had the greatest proportion of particles above $26.9 \mathrm{~mm}$ (1.6 vs. $0.7 \%$ ), but this proportion was not likely great enough to result in an increase in sorting behavior. 
Table 2. Chemical composition, fermentation, and physical characteristics of whole plant corn silage and alfalfa haylage and hay ${ }^{1}$

\begin{tabular}{|c|c|c|c|c|}
\hline Item & $\mathrm{KP}$ & SHRD & Haylage & Hay \\
\hline DM, \% of as fed & $39.0 \pm 4.3$ & $38.4 \pm 3.5$ & $34.6 \pm 1.9$ & $87.0 \pm 1.8$ \\
\hline $\mathrm{OM}, \%$ of DM & $95.5 \pm 1.6$ & $95.6 \pm 1.6$ & $89.7 \pm 0.2$ & $91.4 \pm 0.5$ \\
\hline Soluble $\mathrm{CP}, \%$ of $\mathrm{CP}$ & $46.9 \pm 3.4$ & $48.9 \pm 4.6$ & $67.5 \pm 1.8$ & $37.3 \pm 3.1$ \\
\hline Neutral detergent insoluble CP, $\%$ of DM & $1.2 \pm 0.1$ & $1.1 \pm 0.1$ & $2.9 \pm 0.2$ & $4.8 \pm 0.7$ \\
\hline Acid detergent insoluble CP, \% of DM & $0.5 \pm 0.1$ & $0.5 \pm 0.1$ & $1.8 \pm 0.1$ & $1.6 \pm 0.1$ \\
\hline $\mathrm{ADF}, \%$ of $\mathrm{DM}$ & $27.1 \pm 1.5$ & $26.9 \pm 2.1$ & $43.2 \pm 0.8$ & $45.2 \pm 2.6$ \\
\hline Lignin, \% of DM & $2.3 \pm 0.3$ & $2.2 \pm 0.3$ & $9.1 \pm 0.3$ & $9.9 \pm 1.1$ \\
\hline $30-\mathrm{h}$ ivNDFD, ${ }^{2} \%$ of NDF & $62.6 \pm 6.5$ & $65.2 \pm 5.9$ & $39.0 \pm 1.4$ & $38.4 \pm 3.3$ \\
\hline Starch, \% of DM & $30.8 \pm 4.0$ & $32.2 \pm 2.7$ & - & - \\
\hline \multicolumn{5}{|l|}{ Fermentation profile } \\
\hline $\mathrm{pH}$ & $3.83 \pm 0.03$ & $3.88 \pm 0.13$ & - & - \\
\hline Lactate, \% of DM & $3.4 \pm 0.8$ & $3.0 \pm 0.4$ & - & - \\
\hline \multicolumn{5}{|l|}{ Processing score $^{3}$} \\
\hline Starch & $67.6 \pm 6.5$ & $72.4 \pm 3.6$ & - & - \\
\hline \multicolumn{5}{|l|}{ Penn State separator sieves, ${ }^{4} \%$ as fed retained } \\
\hline $19.0 \mathrm{~mm}$ & $7.1 \pm 2.8$ & $18.3 \pm 6.4$ & $29.6 \pm 4.0$ & $20.1 \pm 9.1$ \\
\hline $8.0 \mathrm{~mm}$ & $68.1 \pm 3.5$ & $54.5 \pm 4.4$ & $55.2 \pm 3.7$ & $23.3 \pm 3.2$ \\
\hline $1.18 \mathrm{~mm}$ & $22.3 \pm 3.5$ & $24.8 \pm 3.2$ & $14.1 \pm 1.1$ & $31.7 \pm 2.9$ \\
\hline Bottom pan & $2.5 \pm 1.2$ & $2.4 \pm 1.1$ & $1.1 \pm 0.5$ & $24.9 \pm 7.6$ \\
\hline \multicolumn{5}{|l|}{ Wisconsin separator sieves, ${ }^{5} \%$ as fed retained } \\
\hline $26.9 \mathrm{~mm}$ & $2.2 \pm 1.3$ & $6.3 \pm 2.3$ & $5.2 \pm 2.1$ & $4.1 \pm 1.9$ \\
\hline $18.0 \mathrm{~mm}$ & $17.2 \pm 3.4$ & $32.5 \pm 2.5$ & $24.4 \pm 3.2$ & $9.3 \pm 3.4$ \\
\hline $8.98 \mathrm{~mm}$ & $51.7 \pm 3.9$ & $32.0 \pm 1.6$ & $45.7 \pm 1.9$ & $16.2 \pm 1.3$ \\
\hline $5.61 \mathrm{~mm}$ & $13.1 \pm 1.0$ & $12.1 \pm 0.7$ & $12.1 \pm 1.2$ & $14.3 \pm 0.8$ \\
\hline $1.65 \mathrm{~mm}$ & $11.0 \pm 1.4$ & $12.5 \pm 1.0$ & $9.6 \pm 1.3$ & $25.0 \pm 2.0$ \\
\hline Bottom pan & $4.8 \pm 1.7$ & $4.6 \pm 1.4$ & $2.9 \pm 0.9$ & $31.0 \pm 4.8$ \\
\hline
\end{tabular}

\footnotetext{
${ }^{1}$ Treatments were conventional-processed corn silage (KP) or corn shredlage (SHRD).

${ }^{2}$ Ruminal in vitro NDF digestibility at $30 \mathrm{~h}$.

${ }^{3}$ Percent passing a 4,750- $\mu \mathrm{m}$ sieve; processing score was measured as described by Ferreira and Mertens (2005).

${ }^{4}$ Particle size was measured using the Penn State particle size separator as described by Kononoff et al. (2003).

${ }^{5}$ Particle size was measured using the Wisconsin oscillating particle separator as described by ANSI (2001).
}

Lactation performance results are in Table 5. Milk yield was greater for cows fed KP and SHRD by 3.4 $\mathrm{kg} / \mathrm{d}$, on average, compared with cows fed $\mathrm{KPH}(P<$ $0.001)$. Although milk yield was only numerically greater by $1.2 \mathrm{~kg} / \mathrm{d}$, on average, for SHRD over KP across the trial, a treatment by week interaction was detected (Figure 2; $P<0.001$ ) with milk yield being or tending to be greater by $1.5 \mathrm{~kg} / \mathrm{d}$, on average, for SHRD over $\mathrm{KP}$ during wk 3, 7, 8, 9, 12, and 14 of treatment. Component-corrected milk yields (FCM, SCM, and ECM) were unaffected $(P>0.10)$ by treatment. Previously, Ferraretto and Shaver (2012) reported a tendency for increased component-corrected milk yields for SHRD compared with KP using a non-BMR hybrid. Milk fat content was 0.37 percentage units greater $(P<0.01)$ for $\mathrm{KPH}$ over the average of KP and SHRD, which were similar $(P>0.10)$. Yields of milk fat were unaffected $(P>0.10)$ by treatment. Greater milk fat content for KPH may be related to decreased starch intake and increased forage NDF intake compared with SHRD and KP (Table 6). The greater-than-formulated starch content of the diets, especially for KP and SHRD, may have caused the differences in milk fat content, which were not overcome by the increased TLOC and particle size of SHRD compared with KP. In addition, diets containing BMR WPCS are often reported to have lower milk fat content (Ferraretto and Shaver, 2015). Yang and Beauchemin (2007) reported that an increase in forage-to-concentrate ratio, and not an increase in TLOC of alfalfa haylage, improved milk fat content when a high-starch diet was fed. It should be noted that the SHRD TLOC (26 vs. $30 \mathrm{~mm}$ ) and particle 


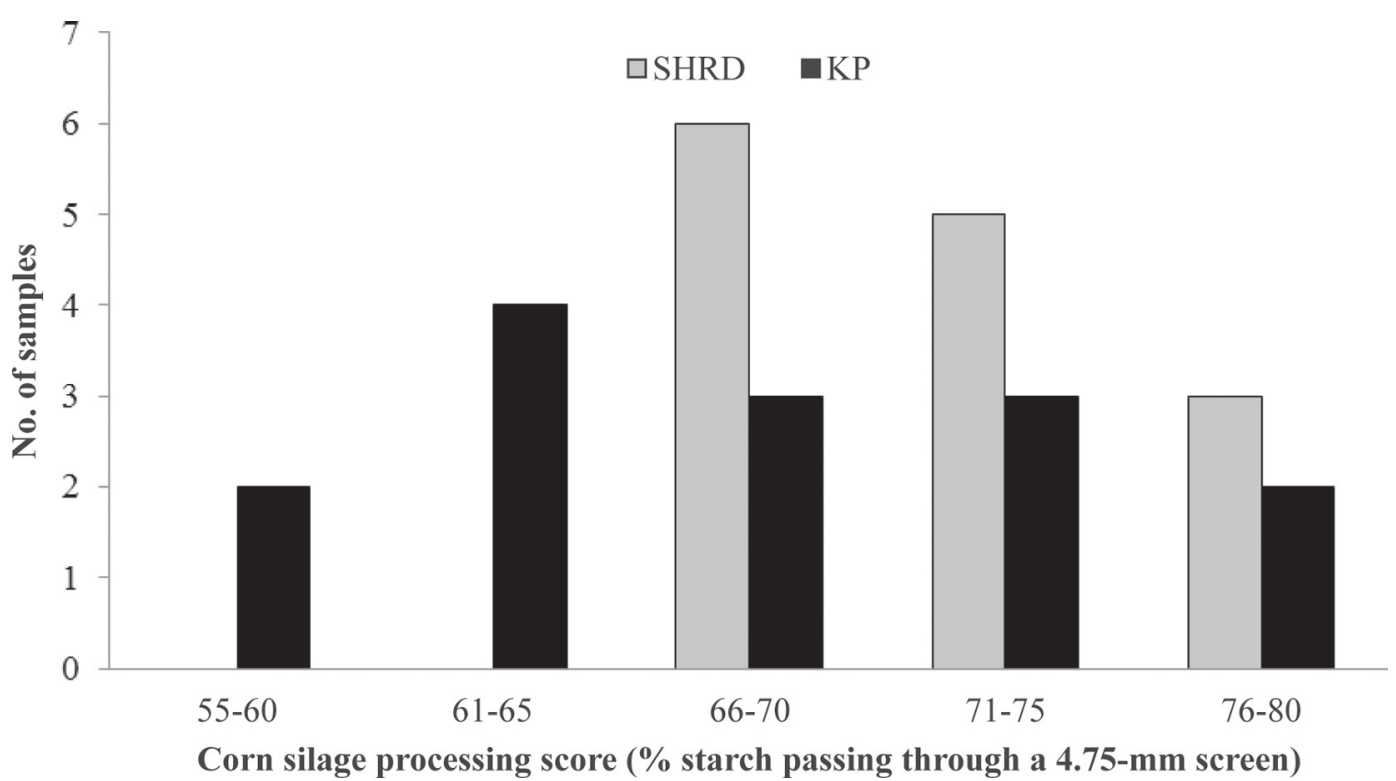

Figure 1. Corn silage processing score (\% of starch passing through a 4.75-mm screen), distribution of corn shredlage (SHRD), and conventional-processed corn silage (KP) on feed-out samples.

size (18 vs. $33 \%$ on the top screen of the PSPS) were reduced in the present study compared with the report of Ferraretto and Shaver (2012).

The reduced particle size of SHRD in the present study may have decreased the peNDF content of SHRD and limited its ability to improve milk fat content com- pared with KP. Rumination time in minutes per day, minutes per kilogram of DMI, and minutes per kilogram of NDF intake were unaffected $(P>0.10)$ by treatment (Table 4), which further supports the foregoing discussion with regard to peNDF. Rumination in minutes per kilogram of forage NDF intake was greater $(P<0.05)$

Table 3. Diet nutrient composition and particle size ${ }^{1}$

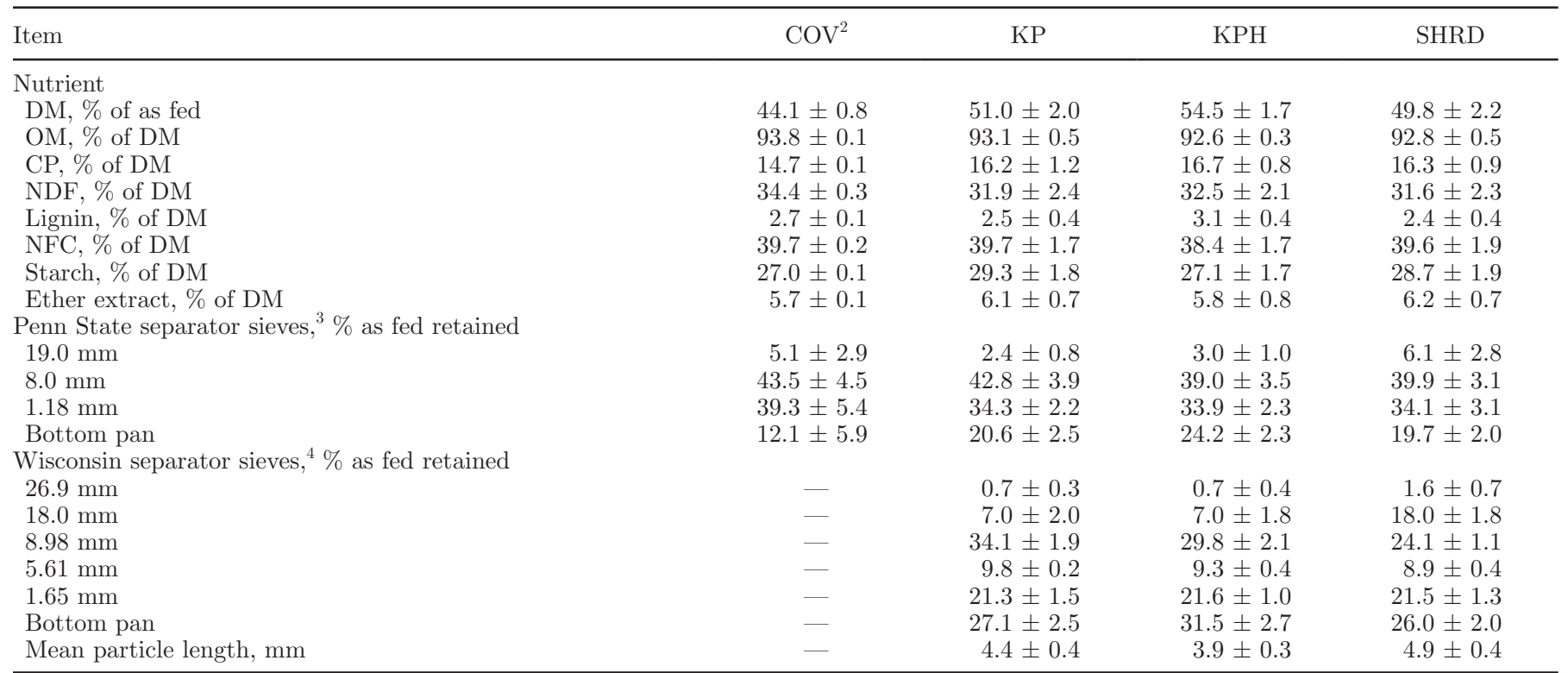

${ }^{1}$ Treatments were diets containing conventional-processed corn silage (KP), KP with hay (KPH), or corn shredlage (SHRD). ${ }^{2} \mathrm{COV}=$ covariate period diet.

${ }^{3}$ Particle size was measured using the Penn State particle size separator as described by Kononoff et al. (2003).

${ }^{4}$ Particle size was measured using the Wisconsin oscillating particle separator as described by ANSI (2001). 
Table 4. Effect of treatment on covariate-adjusted LSM for rumination time and feed sorting ${ }^{1,2}$

\begin{tabular}{|c|c|c|c|c|c|}
\hline Item & $\mathrm{KP}$ & $\mathrm{KPH}$ & SHRD & $\mathrm{SE}$ & $P$-value \\
\hline \multicolumn{6}{|l|}{ Rumination } \\
\hline $\min / \mathrm{d}$ & 503 & 499 & 504 & 9.4 & 0.88 \\
\hline $\min / \mathrm{kg}$ of DMI & 18.9 & 18.7 & 18.8 & 0.2 & 0.69 \\
\hline $\mathrm{min} / \mathrm{kg}$ of NDF intake & 63.7 & 61.9 & 64.1 & 1.2 & 0.17 \\
\hline $\mathrm{min} / \mathrm{kg}$ of forage NDF intake & $84.1^{\mathrm{ab}}$ & $80.0^{\mathrm{b}}$ & $84.9^{\mathrm{a}}$ & 1.6 & 0.02 \\
\hline \multicolumn{6}{|l|}{ Screen, $\%$ of predicted intake } \\
\hline $19.0 \mathrm{~mm}$ & 88.8 & 90.7 & 93.7 & 3.0 & 0.29 \\
\hline $8.0 \mathrm{~mm}$ & 98.8 & 98.8 & 99.4 & 0.2 & 0.03 \\
\hline $1.18 \mathrm{~mm}$ & 100.9 & 101.1 & 100.9 & 0.4 & 0.85 \\
\hline Pan & 102.1 & 101.8 & 102.1 & 0.3 & 0.37 \\
\hline
\end{tabular}

for SHRD compared with KPH. This, however, was a result of increased forage NDF intake (Table 6) for the KPH diet with similar overall rumination activity. Furthermore, use of a BMR hybrid may account for the lack of difference observed in peNDF. Compared with conventional corn silage hybrids, reduced rumination times have been reported for BMR (Taylor and Allen, 2005). The increased length of the SHRD may not have been enough to overcome the low physical effectiveness of the BMR. Both protein and lactose yields were greater $(P<0.02$ and $P<0.001$, respectively) for cows fed SHRD and KP compared with cows fed KPH. This is in relation to the differences in milk yield among the treatments, as milk protein and lactose contents were unaffected by treatment $(P>0.10)$. Reduced milk, protein, and lactose yields for KPH likely resulted from decreased energy supplied by the low-quality hay. Holt et al. (2013) reported no differences in milk or com- ponent yields when a fair- versus high-quality alfalfa hay was fed with BMR WPCS. Although ivNDFD was similar for the hays used in the 2 trials, the NDF and lignin contents were greater in the present study than in the study of Holt et al. (2013). The MUN concentration was greatest for KPH, which may be due in part to the lower starch intake for KPH compared with SHRD and KP (Table 6; Ferraretto et al., 2013). Observed differences in nutrient intakes among treatments were related mostly to differences in TMR nutrient composition as DMI was unaffected $(P>0.10)$ by treatment.

Total-tract dietary nutrient digestibilities are in Table 6. Total-tract DM and OM digestibilities were greater $(P<0.0001)$ for cows fed KP and SHRD than for cows fed KPH. Total-tract NDF digestibility tended to be greatest for $\mathrm{KPH}$ and lowest for SHRD $(P<$ $0.06)$. Because WPCS ruminal in situ NDF digestibility was similar $(P>0.10$; data not presented) for SHRD

Table 5. Effect of treatment on covariate-adjusted LSM for lactation performance ${ }^{1,2,3}$

\begin{tabular}{|c|c|c|c|c|c|}
\hline Item & KP & $\mathrm{KPH}$ & SHRD & $\mathrm{SE}$ & $P$-value \\
\hline \multicolumn{6}{|l|}{ Yield } \\
\hline Milk, kg/d & $50.1^{\mathrm{a}}$ & $47.4^{\mathrm{b}}$ & $51.3^{\mathrm{a}}$ & 0.7 & 0.001 \\
\hline $3.5 \% \mathrm{FCM}, \mathrm{kg} / \mathrm{d}$ & 48.5 & 48.7 & 49.6 & 0.9 & 0.49 \\
\hline $\mathrm{SCM}, \mathrm{kg} / \mathrm{d}$ & 44.9 & 44.8 & 45.9 & 0.8 & 0.39 \\
\hline ECM, kg/d & 48.6 & 48.4 & 49.5 & 0.8 & 0.36 \\
\hline \multicolumn{6}{|l|}{ Milk components } \\
\hline Fat, $\%$ & $3.31^{\mathrm{b}}$ & $3.67^{\mathrm{a}}$ & $3.29^{\mathrm{b}}$ & 0.10 & 0.01 \\
\hline Fat, $\mathrm{kg} / \mathrm{d}$ & 1.66 & 1.74 & 1.68 & 0.05 & 0.24 \\
\hline Protein, \% & 3.13 & 3.14 & 3.09 & 0.03 & 0.22 \\
\hline Protein, kg/d & $1.56^{\mathrm{ab}}$ & $1.50^{\mathrm{b}}$ & $1.59^{\mathrm{a}}$ & 0.02 & 0.02 \\
\hline Lactose, \% & 4.88 & 4.87 & 4.88 & 0.02 & 0.82 \\
\hline Lactose, $\mathrm{kg} / \mathrm{d}$ & $2.44^{\mathrm{a}}$ & $2.31^{\mathrm{b}}$ & $2.50^{\mathrm{a}}$ & 0.04 & 0.001 \\
\hline MUN, mg/dL & $14.3^{\mathrm{b}}$ & $15.3^{\mathrm{a}}$ & $14.7^{\mathrm{ab}}$ & 0.2 & 0.01 \\
\hline
\end{tabular}


Table 6. Effect of treatment on covariate-adjusted LSM for nutrient intake during digestibility weeks and apparent total-tract nutrient digestibility ${ }^{1,2,3,4}$

\begin{tabular}{lccccc}
\hline Item & KP & KPH & SHRD & SE & $P$-value \\
\hline Intake & & & & & \\
$\mathrm{DM}, \mathrm{kg} / \mathrm{d}$ & 26.7 & 26.7 & 26.9 & 0.5 & 0.88 \\
$\mathrm{DM}, \%$ of BW & 3.61 & 3.69 & 3.66 & 0.14 & 0.44 \\
$\mathrm{OM}, \mathrm{kg} / \mathrm{d}$ & 23.1 & 22.9 & 23.2 & 0.4 & 0.82 \\
$\mathrm{NDF}, \mathrm{kg} / \mathrm{d}$ & 7.9 & 8.0 & 7.9 & 0.1 & 0.49 \\
$\mathrm{NDF}, \% \mathrm{BW}$ & 1.07 & 1.11 & 1.07 & 0.02 & 0.05 \\
Forage NDF, kg/d & 6.0 & 6.2 & 6.0 & 0.1 & 0.07 \\
Forage NDF, \%BW & $0.81^{\mathrm{b}}$ & $0.86^{\mathrm{a}}$ & $0.81^{\mathrm{b}}$ & 0.01 & 0.01 \\
Starch, kg/d & $7.2^{\mathrm{a}}$ & $6.7^{\mathrm{b}}$ & $7.2^{\mathrm{a}}$ & 0.1 & 0.01 \\
CP, kg/d & 4.0 & 4.1 & 4.1 & 0.1 & 0.38 \\
Ether extract, kg/d & $1.5^{\mathrm{ab}}$ & $1.4^{\mathrm{b}}$ & $1.5^{\mathrm{a}}$ & 0.02 & 0.01 \\
Digestibility, \% of intake & & & & & \\
DM & $66.6^{\mathrm{a}}$ & $64.0^{\mathrm{b}}$ & $66.8^{\mathrm{a}}$ & 0.5 & 0.001 \\
OM & $68.8^{\mathrm{a}}$ & $66.7^{\mathrm{b}}$ & $69.4^{\mathrm{a}}$ & 0.5 & 0.001 \\
NDF & 40.8 & 41.7 & 38.9 & 1.1 & 0.06 \\
Starch & $98.6^{\mathrm{b}}$ & $98.9^{\mathrm{ab}}$ & $99.1^{\mathrm{a}}$ & 0.1 & 0.01 \\
\hline
\end{tabular}

a,b Means in the same row with different superscripts differ $(P \leq 0.05)$.

${ }^{1}$ Treatments were diets containing conventional-processed corn silage (KP), KP with hay (KPH), or corn shredlage (SHRD).

${ }^{2}$ Week effect $(P<0.05)$ for all parameters except for digestibility of $\mathrm{CP}$ and starch.

${ }^{3}$ Treatment $\times$ week effect $(P<0.05)$ for all parameters except digestibility of starch.

${ }^{4}$ Determined using lignin as an internal marker.

and KP, the reduced total-tract NDF digestibility for SHRD may be related to greater dietary starch content for SHRD compared with KPH and greater kernel processing and ruminal starch digestibility for SHRD compared with KP and KPH (Johnson et al., 1999; Ferraretto et al. 2013). The WPCS ruminal in situ

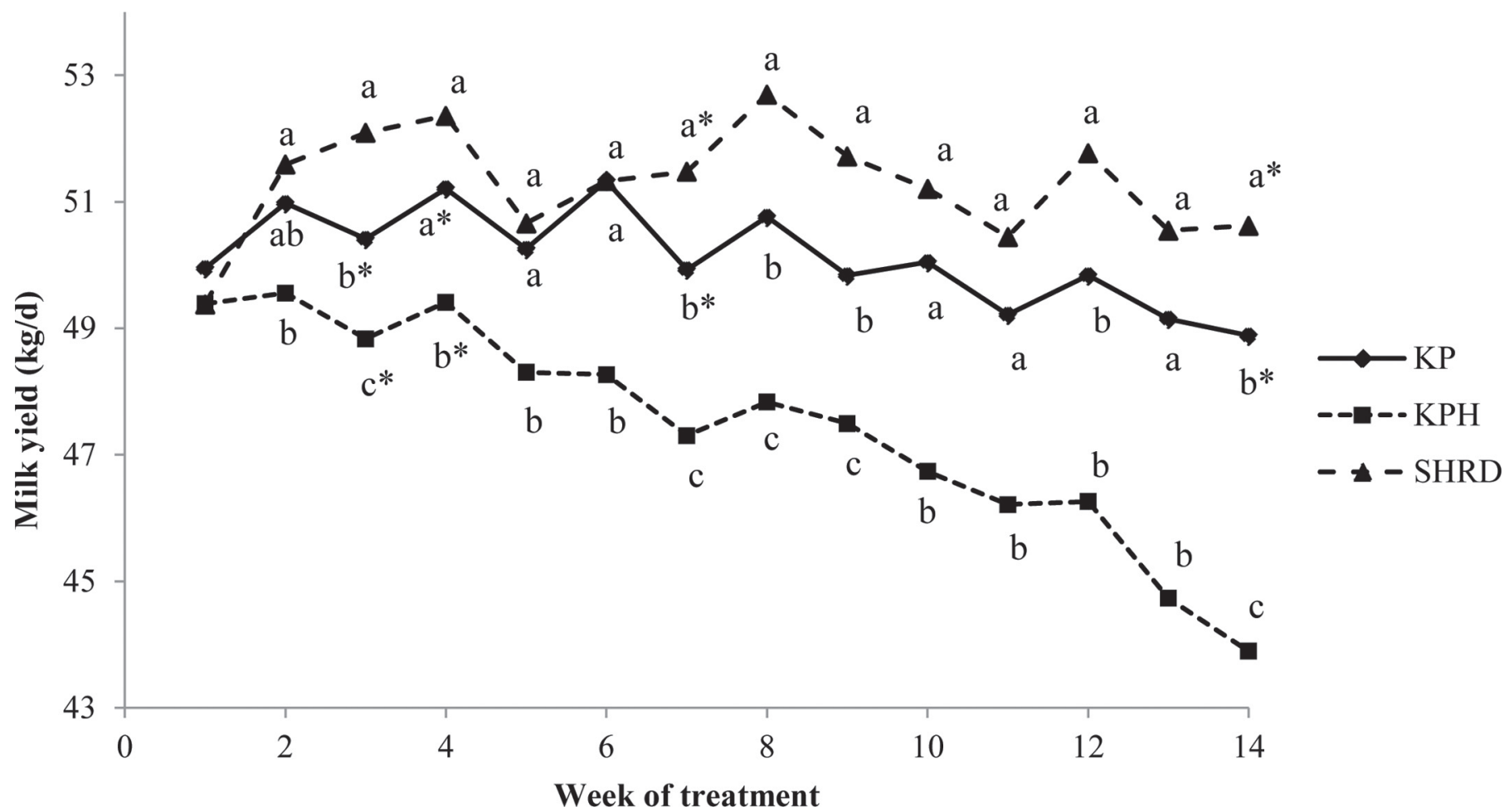

Figure 2. Effect of treatment on milk yield $(\mathrm{kg} / \mathrm{d})$ as covariate-adjusted LSM by week on treatment. Treatments were diets containing conventional-processed corn silage $(\mathrm{KP}), \mathrm{KP}$ with hay $(\mathrm{KPH})$, or corn shredlage $(\mathrm{SHRD})$. Week $\times$ Treatment interaction effects $(P<0.001)$ were noted; SEM $=0.7$. Means within the same week with different superscripts $\left(\mathrm{a}^{-} \mathrm{c}\right)$ differ $(P<0.05)$ or tend $(P<0.10)$ to differ $\left(\mathrm{a}^{*}-\mathrm{c}^{*}\right)$. 
Table 7. Effect of treatment on covariate-adjusted LSM for BW, BCS, and feed efficiency, and unadjusted means for BW change and estimated diet energy concentrations ${ }^{1,2,3}$

\begin{tabular}{lccccc}
\hline Item & KP & KPH & SHRD & SE & $P$-value \\
\hline BW, $\mathrm{kg}$ & 738 & 727 & 733 & 4.9 & 0.10 \\
$\mathrm{BW}$ change, $\mathrm{kg} / \mathrm{d}$ & 0.57 & 0.44 & 0.65 & 0.10 & 0.18 \\
$\mathrm{BCS}$ & 3.09 & 3.11 & 3.10 & 0.03 & 0.88 \\
Feed conversion & & & & & \\
$\mathrm{kg}$ of milk/kg of DMI & $1.88^{\mathrm{a}}$ & $1.78^{\mathrm{b}}$ & $1.90^{\mathrm{a}}$ & 0.02 & 0.01 \\
$\mathrm{~kg}$ of $3.5 \% \mathrm{FCM} / \mathrm{kg}$ of DMI & 1.81 & 1.84 & 1.84 & 0.04 & 0.54 \\
$\mathrm{~kg}$ of SCM $/ \mathrm{kg}$ of DMI & 1.68 & 1.69 & 1.70 & 0.03 & 0.76 \\
$\mathrm{~kg}$ of ECM $/ \mathrm{kg}$ of DMI & 1.82 & 1.82 & 1.84 & 0.03 & 0.68 \\
Estimated diet NE, Mcal $/ \mathrm{kg}_{\mathrm{L}}$ of $\mathrm{DMI}^{4}$ & 1.79 & 1.78 & 1.81 & 0.03 & 0.55 \\
\hline
\end{tabular}

${ }^{\mathrm{a}, \mathrm{b}}$ Means in the same row with different superscripts differ $(P \leq 0.05)$.

${ }^{1}$ Treatments were diets containing conventional-processed corn silage (KP), KP with hay (KPH), or corn shredlage (SHRD).

${ }^{2}$ Week effect $(P<0.05)$ for all parameters except BW change and estimated diet $\mathrm{NE}_{\mathrm{L}}$ which were determined across the 14 -wk treatment period.

${ }^{3}$ Treatment $\times$ week effect $(P<0.05)$ for all parameters except BW $(P<0.10)$ and BCS $(P>0.10)$.

${ }^{4}$ Calculated by summing the Mcal of $\mathrm{NE}_{\mathrm{L}}$ from milk production, required for maintenance, and in $\mathrm{BW}$ change (NRC, 2001) and then dividing the sum by DMI.

starch digestibility was greater $(P<0.01)$ for SHRD than KP (87.3 vs. $76.6 \%$, respectively). This is in agreement with Ferraretto and Shaver (2012), who reported an improvement of 7.0 percentage units in ruminal in situ starch digestibility for SHRD compared with KP WPCS. The ttSTD was greater $(P<0.01)$ for SHRD than KP. Similarly, ttSTD calculated using the fecal starch concentration equation of Fredin et al. (2014) was greater $(P<0.05)$ for SHRD than KP. Treatment means for ttSTD calculated using fecal starch were 98.5, 98.9, and 99.0\% for KP, KPH, and SHRD, respectively. Differences in ttSTD between SHRD and KP were, however, biologically small (0.5 percentage units) and near $100 \%$ for all treatments. Small differences in ttSTD along with much larger differences ruminally may be explained by postruminal compensatory digestion of starch (Ferraretto et al., 2013). Nearly complete digestion of starch in the total tract may be explained by the almost 6 -mo lag between ensiling and the midpoint of the feeding trial, as length of the ensiling period has been shown to increase starch digestibility in WPCS (Der Bedrosian et al., 2012).

Body weight, BWC, BCS, and feed efficiency results are in Table 7. Feed efficiency (kilograms of actual milk yield per kilogram of DMI) was greater $(P<0.01)$ for SHRD and KP than KPH, whereas component-corrected milk feed efficiencies were unaffected $(P>0.10)$ by treatment. Lower feed efficiency when cows were fed the KPH diet may be related to decreased $(P<0.001$; Table 6) digestibility of DM and OM and corresponding lower energy availability for lactation performance. Body weight, BWC, BCS, and diet energy content estimated from animal measurements were unaffected by treatment $(P>0.10)$.

\section{CONCLUSIONS}

Under the conditions of this study with a BMR hybrid and cows producing approximately $50 \mathrm{~kg} / \mathrm{d}$ per cow, feeding SHRD increased or tended to increase milk yield by $1.5 \mathrm{~kg} / \mathrm{d}$ per cow compared with $\mathrm{KP}$, on average, during 6 of the 14 wk of the study. The CSPS was greater and less variable for SHRD than KP, supporting previous findings from our laboratory that SHRD can allow for an increased TLOC without compromising the degree of kernel processing. Despite the increased TLOC, no improvement in milk fat content or rumination activity was observed for SHRD compared with KP. Cows fed SHRD had lower milk fat content than cows fed KPH, further suggesting no improvement in peNDF for SHRD. Starch digestibility was greater for SHRD than KP.

\section{ACKNOWLEDGMENTS}

Appreciation is extended to Mycogen Seeds (Indianapolis, IN) for partially funding this project; the staff at the University of Wisconsin-Madison Agricultural Research Station for corn production and corn silage harvest and storage; Mike Peters and Sandy Trower and their staff at the University of Wisconsin-Madison Blaine Dairy Cattle Center for animal care and trial management; SCR/Vocal Tag (Netanya, Israel) for the collars and wireless system used to determine rumination activity.

\section{REFERENCES}

American National Standards Institute. 2001. American National Standards Institute, Method of Determining and Expressing Par- 
ticle Size of Chopped Forage Materials by Sieving, Standards. Am. Soc. Agric. Eng. St. Joseph, MI.

AOAC International. 2012. Official Methods of Analysis. 19th ed. AOAC International, Arlington, VA.

Bach Knudsen, K. E. 1997. Carbohydrate and lignin contents of plant materials used in animal feeding. Anim. Feed Sci. Technol. 67:319-338.

Baker, S., and T. Herrman. 2002. Evaluating Particle Size. Publ. MF2051. Kansas State Univ. Coop. Ext. Serv., Manhattan.

Bal, M. A., R. D. Shaver, A. G. Jirovec, K. J. Shinners, and J. D. Coors. 2000. Crop processing and chop length of corn silage: Effects on intake, digestion, and milk production by dairy cows. J. Dairy Sci. 83:1264-1273.

Dado, R. G., and M. S. Allen. 1995. Intake limitations, feeding behavior, and rumen function of cows challenged with rumen fill from dietary fiber or inert bulk. J. Dairy Sci. 78:118-133.

Der Bedrosian, M. C., L. Kung Jr., and K. E. Nestor Jr.. 2012. The effects of hybrid, maturity and length of storage on the composition and nutritive value of corn silage. J. Dairy Sci. 95:5115-5126.

Ferraretto, L. F., P. M. Crump, and R. D. Shaver. 2013. Effect of cereal grain type and corn grain processing methods on intake, digestion, and milk production by dairy cows through a meta-analysis. J. Dairy Sci. 96:533-550.

Ferraretto, L. F., and R. D. Shaver. 2012. Effect of corn shredlage on lactation performance and total tract starch digestibility by dairy cows. Prof. Anim. Sci. 28:639-647.

Ferraretto, L. F., and R. D. Shaver. 2015. Effects of whole-plant corn silage hybrid type on intake, digestion, ruminal fermentation, and lactation performance by dairy cows through a meta-analysis. J. Dairy Sci. 98:2662-2675.

Ferreira, G., and D. R. Mertens. 2005. Chemical and physical characteristics of corn silages and their effects on in vitro disappearance. J. Dairy Sci. 88:4414-4425.

Fredin, S. M., L. F. Ferraretto, M. S. Akins, P. C. Hoffman, and R. D. Shaver. 2014. Fecal starch as an indicator of total-tract starch digestibility by lactating dairy cows. J. Dairy Sci. 97:1862-1871.

Holden, L. A. 1999. Comparison of methods of in vitro dry matter digestibility for ten feeds. J. Dairy Sci. 82:1791-1794.

Holm, S. 1979. A simple sequentially rejective multiple test procedure. Scand. J. Stat. 6:65-70.

Holt, M. S., K. Neal, J.-S. Eun, A. J. Young, J. O. Hall, and K. E. Nestor Jr. 2013. Corn silage hybrit type and quality of alfalfa hay affect dietary nitrogen utilization by early lactating dairy cows. J. Dairy Sci. 96:6564-6576.

Johnson, L., J. H. Harrison, C. Hunt, K. Shinners, C. G. Doggett, and D. Sapienza. 1999. Nutritive value of corn silage as affected by maturity and mechanical processing: A contemporary review. J. Dairy Sci. 82:2813-2825.
Kononoff, P. J., A. J. Heinrichs, and D. R. Buckmaster. 2003. Modification of the Penn State forage and total mixed ration particle separator and the effects of moisture content on its measurements. J. Dairy Sci. 86:1858-1863.

Kung, L., and R. Shaver. 2000. Interpretation and use of silage fermentation analysis report. Accessed Nov. 24, 2014. http://fyi.uwex. edu/forage/files/2014/01/Fermentation.pdf.

Leonardi, C., and L. E. Armentano. 2003. Effect of quantity, quality and length of alfalfa hay on selective consumption by dairy cows. J. Dairy Sci. 86:557-564.

Leonardi, C. K. J. Shinners, and L. E. Armentano. 2005. Effect of different dietary geometric mean particle length and particle size distribution of oat silage on feeding behavior and productive performance of dairy cattle. J. Dairy Sci. 88:698-710.

Mertens, D. R. 1997. Creating a system for meeting the fiber requirements of dairy cows. J. Dairy Sci. 80:1463-1481.

Muck, R. E., and J. T. Dickerson. 1988. Storage temperature effects on proteolysis in alfalfa silage. Trans. ASABE 31:1005-1009.

NRC. 2001. Nutrient Requirements of Dairy Cattle. 7th rev. ed. Natl. Acad. Sci., Washington, DC.

Oba, M., and M. S. Allen. 2000. Effects of brown midrib 3 mutation in corn silage on productivity of dairy cows fed two concentrates of dietary neutral detergent fiber: 2. Chewing activities. J. Dairy Sci. 83:1342-1349

SAS Institute. 2004. SAS/STAT 9.1 User's Guide. Version 9.1 ed. SAS Institute Inc., Cary, NC.

Taylor, C.C., and M. S. Allen. 2005. Corn endosperm type and brown midrib 3 corn silage: Feeding behavior and milk yield of lactating dairy cows. J. Dairy Sci. 88:1425-1433.

Van Soest, P. J., J. B. Robertson, and B. A. Lewis. 1991. Methods for dietary fiber, neutral detergent fiber, and nonstarch polysaccharides in relation to animal nutrition. J. Dairy Sci. 74:3583-3597.

Wildman, E. E., G. M. Jones, P. E. Wagner, R. L. Boman, H. F Troutt, and T. N. Lesch. 1982. A dairy-cow body condition scoring system and its relationship to selected production characteristics. J. Dairy Sci. 65:495-501.

Yang, W. Z., and K. A. Beauchemin. 2007. Altering physically effective fiber intake through forage proportion and particle length: Digestion and milk production. J. Dairy Sci. 90:3410-3421.

Yang, W. Z., K. A. Beauchemin, and L. M. Rode. 2001. Effects of grain processing, forage to concentrate ratio, and forage particle size on rumen $\mathrm{pH}$ and digestion by dairy cows. J. Dairy Sci. $84: 2203-2216$

Zebeli, Q., J. R. Aschenbach, M. Tafaj, J. Boguhn, B. N. Ametaj, and W. Drochner. 2012. Invited review: Role of physically effective fiber and estimation of dietary fiber adequacy in high-producing dairy cattle. J. Dairy Sci. 95:1041-1056. 